\title{
About the contributors
}

Philip Arestis is University Director of Research, Cambridge Centre for Economic and Public Policy, Department of Land Economy, University of Cambridge, UK, Adjunct Professor of Economics at the University of Utah, USA and Senior Scholar at the Levy Economics Institute, New York, USA. He is also Visiting Professor, University of Leeds, UK, and School of Oriental and African Studies (SOAS), University of London, UK. He was a member of the Economics and Econometrics RAE panels in 1996 and 2001. His research interests are in the areas of Macroeconomics, Monetary Economics, Applied Econometrics, Political Economy and Applied Political Economy. He has published as sole author or editor, as well as co-author and co-editor, a number of books, and in academic journals.

John Cornwall is Professor Emeritus at Dalhousie University, Halifax, Canada and Associate Member, Cambridge Centre for Economic and Public Policy, University of Cambridge, UK. He has authored and edited several books on theoretical and applied macroeconomics including Growth and Stability in a Mature Economy (1972), Modern Capitalism (1977), Economic Recovery for Canada (with Wendy Maclean; 1984), The Theory of Economic Breakdown (1990) and Capitalist Development in the Twentieth Century (with Wendy Cornwall; 2001). His articles have appeared in such journals as Review of Economics and Statistics, Quarterly Journal of Economics. American Economic Review, Kyklos, Economic Journal, Journal of Post-Keynesian Economics, and Journal of Economic Issues.

Paul Davidson is Editor of the Journal of Post Keynesian Economics. He is currently a Visiting Scholar at the Bernard Schwartz Center for Economic Policy Analysis of the New School in New York City. Previously he occupied the Holly Chair of Excellence of Political Economy at the University of Tennessee. He has also had professorships at Rutgers University and the University of Pennsylvania. He has also had visiting appointments at Bristol University and Cambridge University in the UK and the Institute for Advanced Studies in Vienna. He was also the Assistant Director of the Economics Division of the Continental Oil Company. 
Valpy FitzGerald is Professor of International Economics and Finance, Director of the Finance and Trade Policy Centre and Professorial Fellow of St Antony's College at Oxford University. His recent books include Global Markets and the Developing Economy (Basingstoke: Palgrave, 2003) and The Transmission of Economic Ideas in Latin America (Basingstoke: Palgrave, 2005). He is currently engaged on research into long-run economic development in Latin America, the determinants of portfolio investment flows towards emerging markets and the relationship between taxation and income distribution.

Heather D. Gibson is Head of the Special Studies Division in the Economic Research Department of the Bank of Greece. Among her duties is responsibility for the Bank's Economic Bulletin as well as the publication of their working paper series. Before joining the Bank of Greece, she was a Lecturer in Economics at the University of Kent. Her main interests include European integration, comparative financial systems, international financial flows and exchange rate systems. She has authored several books and has published widely in journals.

G.C. Harcourt was born in Melbourne, Australia. He is a graduate of Melbourne and Cambridge Universities. He is Emeritus Reader in the History of Economic Theory, Cambridge University (1998), Emeritus Fellow, Jesus College, Cambridge (1998) and Professor Emeritus, Adelaide University (1988). Harcourt is author/editor of 24 books, and over 230 articles or chapters in learned journals and edited volumes.

Mohammed Nureldin Hussain was Division Chief of the African Development Bank's Research Division from 2002 until his tragic death in July 2005. He held a $\mathrm{PhD}$ in Economics from the University of Kent at Canterbury. He acquired 25 years of experience in development economics through teaching, research and application. His work experience includes 9 years as a development practitioner with the African Development Bank, and over 16 years as teaching assistant, lecturer, and associate professor of economics in several universities. His writings have been published widely, covering issues of relevance to Africa's development with original and recognised contributions to development theory and practice.

John McCombie is Director of the Centre for Economic and Public Policy, University of Cambridge and Fellow in Economics at Downing College, Cambridge. He has previously held appointments in the Departments of Economics at the University of Hull and the University of Melbourne. His major research interests are in regional economics, Keynesian macroeconomics and the causes of growth disparities (which includes balance-of-payments constrained growth 
models and a critique of the measurement of technical change using the neoclassical aggregate production function). He has published and co-edited several books, as well as published widely in economic journals.

Miguel A. León-Ledesma ( $\mathrm{PhD}$, La Laguna) is a Senior Lecturer in Economics at the University of Kent. His main research areas are Macroeconomics, Applied Econometrics, and Economic Growth. Together with Tony Thirlwall he developed the concept of the 'endogenous natural rate of growth'. His research has been published in several journals such as Cambridge Journal of Economics, Journal of Macroeconomics, Journal of International Money and Finance and Scottish Journal of Political Economy. He has been consultant for the Central Bank of the Dominican Republic and the European Central Bank.

Mark Roberts is a Fellow in Economics at New Hall and an Affiliated Lecturer in Regional Economics at the University of Cambridge. He is also a member of the Cambridge Centre for Economic and Public Policy, where he is currently engaged in collaborative work on the determinants of spatial disparities in rates of productivity, efficiency and technical change within the EU. His other research interests include the theory and empirics of economic growth from a Kaldorian perspective. He has published in several journals including International Review of Applied Economics, Journal of Regional Science, Regional Studies and The Manchester School, as well as in a range of edited books.

Malcolm Sawyer is Professor of Economics, University of Leeds. He is managing editor of International Review of Applied Economics, managing co-editor of International Papers in Political Economy and joint editor of Journal of Income Distribution. He is the editor of the series New Directions in Modern Economics published by Edward Elgar. He is the author of 11 books, has edited 18 books and has published nearly 150 articles and chapters.

Mark Setterfield is Professor of Economics in the Department of Economics at Trinity College, Hartford, Connecticut and Associate Member, Cambridge Centre for Economic and Public Policy, University of Cambridge, UK. His main research interests are macrodynamics (with a particular focus on concepts of path dependence) and Post-Keynesian economics. He has written and edited several books, and has published in numerous journals including the Cambridge Journal of Economics, Journal of Post Keynesian Economics, European Economic Review, Review of Political Economy, Journal of Economic Issues and The Manchester School.

Ajit Singh is Professor of Economics at Cambridge University and Senior Fellow at Queens' College. His research spans three areas: (i) The theory of the 
firm and industrial organisation including the role of the stock market and the relationship between law, finance and industrial development; (ii) De-industrialisation and structural change in developed and developing countries; and (iii) Economic policy and development. He has written several books and published extensively in leading economic journals. He has been a senior economic advisor to the governments of Mexico and Tanzania and a consultant to various UN developmental organisations.

Roberto Tamborini is Head of the Economics Department at the University of Trento, Italy and was appointed in 2001. He did his first degree (Graduation in Economics) at the University of Modena in 1982 and subsequently did postgraduate work at the University of Cambridge (M.Phil. in Economics) and at the European Institute, Florence ( $\mathrm{PhD}$ in Economics). He has undertaken a period of research at the University of California at Berkeley, USA and has been a Visiting Scholar at Boston University, USA and IDEFI-CNRS, Sophia-Antipolis, Nice, France. His research in recent years has mainly concentrated on macroeconomic theories and policies, money and financial markets, and policies and institutions.

Ferdinando Targetti has a Laurea in Economics and Business Studies from Bocconi University in Milan and has done postgraduate work at Cambridge University. Since 1984 he has been Professor of Economic Policy at the University of Trento, and since 2001 he has been the Director of the postgraduate School of International Studies. His research interests include Italian economic development, the theory of value and distribution, the history of economic thought (Kaldor and Kalecki), international economics, and Italian fiscal reform and budget policy. He has published widely in journals, books and edited volumes. Between 1996 and 2001 he was a member of the Italian Parliament and the Public Finance Commission.

John Toye was educated at Cambridge University, Harvard University and SOAS at London University. He has been professor of development economics at (successively) the universities of Wales, Sussex and Oxford, where he also directed Centres or Institutes of development studies. He has worked for short periods in the British civil service (HM Treasury), the private sector (as director of CRU Ltd) and the United Nations (as a Director of UNCTAD). He has also been consultant for DFID (formerly ODA), the World Bank, the European Commission, ILO, WHO, the Commonwealth Secretariat and the US Overseas Development Council. He is the author of seven books and numerous journal articles.

Euclid Tsakalotos is a Professor in the Department of International and European Economic Studies at Athens University of Economics and Business. 
Previously he was a Lecturer in Economics at the University of Kent. His interests lie in a number of areas of economics, including macroeconomics and European integration, financial and industrial economics, labour economics and political economy. The common theme in much of his work is the importance of institutions and their impact on economic performance. He has published articles, books, and contributions to edited volumes, with his papers having appeared in a number of journals.

Roger Vickerman is Professor of European Economics and Head of the Department of Economics at the University of Kent, Canterbury, UK. He studied Economics at Clare College, Cambridge, has a DPhil in Economics from the University of Sussex and an honorary doctorate in Economics from the Phillipps-Universität Marburg. His main research interests are the relationship between transport (especially infrastructure), regional development and integration in the European Union; and the role of migration and labour mobility in integration. He was a member of the Standing Advisory Committee on Trunk Road Assessment (SACTRA) in the UK contributing to its major report on Transport and the Economy, and has recently been involved in a number of studies on transport developments in the EU. He has served as an advisor to committees of both Houses of Parliament and acted as a consultant to the European Commission, various UK government departments and regional and local government authorities. 
Philip Arestis, John S.L. McCombie, and Roger Vickerman - 9781847204080 Downloaded from PubFactory at 04/26/2023 11:02:56AM 